Research Article

\title{
Timing and Application Rate for Sequential Applications of Glufosinate are Critical for Maximizing Control of Annual Weeds in LibertyLink ${ }^{\circledR}$ Soybean
}

\author{
Chris J. Meyer $(D)$ and Jason K. Norsworthy \\ Department of Crop, Soil and Environmental Sciences, University of Arkansas, Fayetteville, Arkansas, USA \\ Correspondence should be addressed to Chris J. Meyer; christopher.j.meyer@corteva.com
}

Received 13 December 2019; Revised 19 March 2020; Accepted 26 March 2020; Published 4 July 2020

Academic Editor: Daryl Bowman

Copyright ( 2020 Chris J. Meyer and Jason K. Norsworthy. This is an open access article distributed under the Creative Commons Attribution License, which permits unrestricted use, distribution, and reproduction in any medium, provided the original work is properly cited.

\begin{abstract}
Preserving the utility of glufosinate in both LibertyLink soybean and other glufosinate-resistant crops is critical for managing herbicide-resistant weeds. An experiment with a two-factor factorial arrangement was conducted at the Arkansas Agricultural Research and Extension Center in Fayetteville, AR, in 2015, 2016, and 2017 to evaluate the efficacy of glufosinate in single and sequential applications at various rates on $8-32 \mathrm{~cm}$ tall Palmer amaranth, barnyardgrass, and broadleaf signalgrass. Herbicide treatments consisted of glufosinate applied at 454,595, 738, and $882 \mathrm{~g}$ ai ha $^{-1}$ (Factor 1) with either no sequential application or a sequential application occurring 7, 10, 14, or 21 days after the initial application (DAI) (Factor 2). For treatments that contained a sequential application, the same rate used in the initial application (e.g., $451 \mathrm{~g}$ ai ha ${ }^{-1}$ ) was also used in the sequential. Regardless of species and rate, sequential applications were always superior to single applications. Palmer amaranth control 3 weeks after the final treatment (WAF) was $8 \%$ greater when the sequential application occurred 10 DAI compared to 21 DAI, averaged over glufosinate rates. When at least $595 \mathrm{~g}$ ai ha ${ }^{-1}$ glufosinate was used in a treatment, no differences between the 7-, 10-, 14-, and 21day sequential application intervals were observed for barnyardgrass or broadleaf signalgrass control, 3 WAF. Soybean yields were greater when the glufosinate applications occurred 7 or $10 \mathrm{~d}$ apart compared to $21 \mathrm{~d}$, averaged over glufosinate rates. When large weeds are present in the field, these data suggest that glufosinate should be applied sequentially with a 7- to 14-day interval between applications. If sequential applications of glufosinate are used in combination with a comprehensive weed control management program, the value of the LibertyLink technology should be preserved by mitigating the risk of glufosinate resistance.
\end{abstract}

\section{Introduction}

Glufosinate-resistant cultivars began to increase in popularity as a tactic to help manage glyphosate-resistant weeds such as Palmer amaranth [1]. Glufosinate is effective at controlling glyphosate-resistant Palmer amaranth; however, as the use of glufosinate increases, so does the potential for improper management and likelihood of evolving resistance. Glufosinate has no confirmed cases of resistance in row crops [2]. However, confirmation of glufosinate-resistant grass species in orchards highlights the importance of proper management [2]. Identifying management strategies that maximize the effectiveness and utility of glufosinate in LibertyLink systems is of utmost importance because failure to do so will likely accelerate selection for multiple-resistant weeds (e.g., Palmer amaranth resistant to glyphosate and glufosinate) [3]. Resistance modeling conducted by Bagavathiannan et al. [3] describes that failing to control the evolution of resistance in a crop with one herbicide-resistance trait increases the likelihood of evolving resistance in a subsequent or different herbicide-resistance trait.

One of the 12 best management practices (BMPs) to mitigate against herbicide resistance, as described by Norsworthy et al. [4] is to use the full labeled rate of a herbicide at the recommend weed size on the label. In soybean, the single application use rate for glufosinate ranges from 450 to $882 \mathrm{~g}$ ai ha ${ }^{-1}$ with a yearly maximum of $1,734 \mathrm{~g}$ ai ha ${ }^{-1}$ [4]. The glufosinate label allows for multiple 
applications POST, and sequential applications are needed for acceptable control of many broadleaf and grass species [5-7]. Sequential applications are needed for acceptable control of Palmer amaranth [5], and glufosinate applications appear to be sensitive to weed heights, with the control decreasing when heights increase from 10 to $15 \mathrm{~cm}$ [8].

Although herbicide-resistance management principles emphasize the importance of using a preemergence (PRE) herbicide at planting [4], a variety of circumstances may result in a grower either not being able to apply a PRE herbicide or the PRE herbicide being ineffective. In a LibertyLink system, not applying a PRE herbicide would place a great pressure on glufosinate to control a broad spectrum and high density of weeds POST, a scenario highly undesirable for herbicide-resistance management.

Dry conditions can reduce the efficacy of PRE herbicides, resulting in poor control and weed escapes, which compete with the emerging crop and must be controlled POST. The availability of herbicides in the soil solution is critical for root uptake, particularly when the compound is lipophilic [9]. A moderate $(1.2-2.5 \mathrm{~cm})$ amount of rainfall within 2 weeks of application can be critical for maximizing efficacy of certain soil-applied herbicides, such as atrazine, and too little, or too much, rainfall can reduce their effectiveness [10]. Even so, the impact of soil moisture on herbicide efficacy also depends on the individual herbicide, with some (e.g., acetochlor) providing acceptable control under dry conditions and others (e.g., $S$-metolachlor) being more sensitive to rainfall for the herbicidal activity [11].

Poor weather and field conditions can create challenges to successfully complete timely field operations such as planting and spraying herbicides. For example, from May 1 through May 14, 2017, only $3.6 \mathrm{~d}$ were suitable for fieldwork in Arkansas, during a period in which 23\% of the soybean acreage would have been planted in a normal year [12]. Other factors, such as soil properties, can compound poor weather conditions. A large percentage of row-crop acreage in Arkansas consists of somewhat poorly to poorly drained soils [12-14]. For growers who plant soybean on poorly drained soils in the Mississippi Delta region, it is possible that weather and field conditions could make it impossible for PRE applications before crop emergence. With a limited number of POST herbicides available to control widespread glyphosate-resistant Palmer amaranth, proper management of glufosinate is critical in undesirable situations where no PRE herbicide is applied.

Palmer amaranth is capable of emerging at extremely high densities, exceeding 1,000 plants $\mathrm{m}^{-2}$ year $^{-1}$ in some situations [15]. Within four weeks of emergence with the crop, Palmer amaranth can outgrow soybean by $20 \mathrm{~cm}$ and cause yield losses exceeding $60 \%$ at densities of only 10 plants $\mathrm{m}^{-2}[16,17]$. Nine days after emergence, Palmer amaranth can reach and exceed a height of $10 \mathrm{~cm}$ [18], the maximum height allowed on the glufosinate label for this particular weed [19]. The aforementioned findings demonstrate how rapidly Palmer amaranth can become unmanageable in agricultural systems.

The concept of the "critical period of weed control" (CPWC) is fundamental for understanding the risk of yield loss to early weed interference. The CPWC for a given cropping system is defined as the interval a crop must remain weed free to prevent unacceptable yield loss [20]. Even within a given crop, the CPWC will vary with production practices (e.g., row spacing), environment, weeds present, and others [21,22]. More recently, crop competition studies have determined that early-season weed interference can cause irreversible physiological changes that can be associated with yield loss. For example, Green-Tracewicz [23] determined that from V1 to V3 (first trifoliate to third trifoliate), soybean is highly sensitive to changes in red : farred (R:FR) light ratios caused by shading. Exposure to low $\mathrm{R}$ : FR ratios from V1 to V3 will cause an increase in plant height, internode length, and shoot:root ratio with decreases in biomass and leaf number.

When no PRE herbicide is applied and conditions are not suitable for fieldwork, weeds can emerge and compete with the crop during its critical early stages of development, causing yield loss. However, even in field situations with high densities of weeds rapidly overtaking a crop, it may still be desirable to keep the crop and initiate an aggressive weed management program instead of crop destruction and replanting. Even with alternatives to herbicides, such as interrow cultivation, larger weeds in the soybean row will need to be controlled with herbicide applications. Alternatively, it is also possible that in situations where most of the weeds are a labeled weed size, a small portion of total population may exceed the label recommendations. The objective of this experiment was to evaluate single and sequential POST applications of glufosinate on large weeds and determine the optimum application window for sequential applications.

\section{Materials and Methods}

An experiment was conducted at the University of Arkansas Agricultural Research and Extension Center in Fayetteville, $\mathrm{AR}$, to evaluate single and sequential glufosinate applications to determine optimum rate structure and interval between applications. Plots 3.7 by $9.1 \mathrm{~m}$ were established on a leaf silt loam in 2015 and 2017 (fine, mixed, active, thermic Typic Albaquults) with $1.5 \%$ organic matter, a $\mathrm{pH}$ of 5.6, $26 \%$ sand, $66 \%$ silt, and $8 \%$ clay, and a Captina silt loam in 2016 (fine-silty, siliceous, active, mesic Typic Fragiudults) with $2.0 \%$ organic matter, a pH of $5.2,18 \%$ sand, $63 \%$ silt, and $19 \%$ clay. A commercially available LibertyLink variety was planted at the time of trial establishment: Credenz 4748 LL (Bayer CropScience LP, Research Triangle Park, NC, USA) in 2015 (322,800 seeds $\left.\mathrm{ha}^{-1}\right)$, Pioneer P53T62LL (DuPont Pioneer, Wilmington, DE, USA) in 2016 (321,100 seeds $\left.\mathrm{ha}^{-1}\right)$, and Pioneer P48T67LL in 2017 (322,800 seeds $\mathrm{ha}^{-1}$ ). Fertilizer and lime were applied based on a soil test and according to University of Arkansas recommendations. Plots were irrigated with an overhead lateral irrigation system (2015 and 2017) or furrow irrigated (2016) as needed.

The experimental design was a randomized complete block with a factorial treatment structure; Factor 1 was the glufosinate rate $\left(451,595,738\right.$, and $882 \mathrm{~g}$ ai ha $\left.^{-1}\right)$ and Factor 2 was the sequential application structure. The five levels for 
TABle 1: Weed heights and densities for three species at the time of the initial herbicide application in 2015, 2016 , and 2017.

\begin{tabular}{|c|c|c|c|c|c|c|}
\hline \multirow{2}{*}{ Species } & \multicolumn{2}{|r|}{2015} & \multicolumn{2}{|r|}{2016} & \multicolumn{2}{|r|}{2017} \\
\hline & Height $(\mathrm{cm})$ & Density (plants $\mathrm{m}^{-2}$ ) & Height $(\mathrm{cm})$ & Density (plants $\mathrm{m}^{-2}$ ) & Height $(\mathrm{cm})$ & Density (plants $\mathrm{m}^{-2}$ ) \\
\hline Palmer amaranth & $10-25$ & 19 & $13-32$ & 4 & $10-20$ & 15 \\
\hline Barnyardgrass & 20 & 1.5 & 20 & $1-7$ & $10-18$ & 2 \\
\hline Broadleaf signalgrass & 23 & 10 & $8-20$ & 1 & $9-15$ & 12 \\
\hline
\end{tabular}

TABle 2: Dates of herbicide applications in 2015, 2016, and 2017 and weather conditions at the time of application at Fayetteville, AR.

\begin{tabular}{|c|c|c|c|c|c|c|c|c|c|c|c|c|}
\hline \multirow[b]{3}{*}{ Application timing } & \multicolumn{12}{|c|}{ Year } \\
\hline & \multicolumn{4}{|c|}{2015} & \multicolumn{4}{|c|}{2016} & \multicolumn{4}{|c|}{2017} \\
\hline & Date & Time & Temp & $\mathrm{RH}$ & Date & Time & Temp & RH & Date & Time & Temp & $\mathrm{RH}$ \\
\hline Initial & $7 / 24 / 15$ & $8: 30 \mathrm{am}$ & 28 & 70 & $6 / 13 / 16$ & $2: 00 \mathrm{pm}$ & 33 & 81 & $6 / 15 / 17$ & $4: 00 \mathrm{pm}$ & 31 & 77 \\
\hline $7 \mathrm{DAI}$ & $7 / 31 / 15$ & 8:00 am & 39 & 69 & $6 / 20 / 16$ & $11: 00 \mathrm{am}$ & 27 & 50 & $6 / 22 / 17$ & $10: 00 \mathrm{pm}$ & 27 & 70 \\
\hline $10 \mathrm{DAI}$ & $8 / 3 / 15$ & $3: 30 \mathrm{pm}$ & 32 & 40 & $6 / 23 / 16$ & $12: 00 \mathrm{pm}$ & 39 & 62 & $6 / 26 / 17$ & $10: 30 \mathrm{am}$ & 23 & 67 \\
\hline 14 DAI & $8 / 7 / 15$ & $9: 15 \mathrm{am}$ & 27 & 60 & $6 / 27 / 16$ & 9:00 am & 23 & 90 & $6 / 30 / 17$ & 10:00 am & 30 & 55 \\
\hline $21 \mathrm{DAI}$ & $8 / 14 / 15$ & 9:30 am & 24 & 65 & $7 / 4 / 16$ & $11: 00 \mathrm{am}$ & 32 & 79 & $7 / 6 / 17$ & 8:00 am & 26 & 75 \\
\hline
\end{tabular}

DAI, days after initial application; RH, relative humidity; Temp, temperature.

the sequential application structure were as follows: no sequential application, initial application followed by ( $\mathrm{fb}$ ) a sequential application $7 \mathrm{~d}$ after the initial application (DAI), initial application $\mathrm{fb}$ sequential $10 \mathrm{DAI}$, initial application fb sequential $14 \mathrm{DAI}$, and initial application $\mathrm{fb}$ sequential 21 DAI. For treatments that contained a sequential application, the same rate used in the initial application (e.g., $451 \mathrm{~g}$ ai ha $^{-1}$ ) was also used in the sequential. The glufosinate used for all treatments was the formulated product Liberty herbicide (Bayer CropScience LP, Research Triangle Park, NC, USA). Each experiment contained four replications.

The first application for all treatments occurred when weeds achieved $20-30 \mathrm{~cm}$ in height, and a list of weeds and their size at application is listed in Table 1. At the time of initial application, soybean stages were V4-V5 in 2015 and 2017 and V5-V6 in 2016. S-metolachlor at 1,390 $\mathrm{g} \mathrm{ai} \mathrm{ha}^{-1}$ was included with the initial treatment to prevent new weed emergence. A list of planting dates, spray dates, and weather conditions at the time of all herbicide applications is compiled in Table 2. A $\mathrm{CO}_{2}$-pressurized backpack sprayer was used to make all herbicide applications calibrated to deliver $141 \mathrm{~L} \mathrm{ha}^{-1}$ spray volume at $276 \mathrm{kPa}$ at $4.8 \mathrm{~km} \mathrm{hr}^{-1}$ through nozzles spaced $51 \mathrm{~cm}$ apart. The boom was equipped with (TeeJet Technologies, Springfield, Illinois) Turbo TeeJet (TT) 110015 nozzles.

Weed control ratings were collected 3 weeks after the final application and at harvest for Palmer amaranth, barnyardgrass, and broadleaf signalgrass. Weed control was visually evaluated on a scale of 0 (no control) to $100 \%$ (complete death of all plants) relative to the nontreated check. At the end of the season, plots were harvested for yield. Data from all three years were pooled [24], and data were subjected to an analysis of variance (ANOVA) using JMP 13 (SAS Institute Inc., Cary, NC). The statistical model included "Glufosinate Rate," "Sequential Application Structure," and the "Glufosinate Rate by Sequential Application Structure" interaction as fixed effects. Site-year and
TABle 3: Palmer amaranth control 3 weeks after the final application for the main effects of glufosinate rate and sequential application timing, averaged over the other factors in Fayetteville, AR, in 2015, 2016, and 2017.

\begin{tabular}{lclc}
\hline Main effect & Level & \multicolumn{2}{c}{ Control $^{\mathrm{b}}(\%)$} \\
\hline \multirow{3}{*}{ Glufosinate rate $^{\mathrm{c}}$} & 451 & 68 & $\mathrm{C}$ \\
& 595 & 75 & $\mathrm{~B}$ \\
& 738 & 79 & $\mathrm{~A}$ \\
& 882 & 81 & $\mathrm{~A}$ \\
\hline \multirow{3}{*}{ Sequential application timing } & None & 51 & $\mathrm{D}$ \\
& 7 DAI & 84 & $\mathrm{Ab}$ \\
& $10 \mathrm{DAI}$ & 86 & $\mathrm{~A}$ \\
& $14 \mathrm{DAI}$ & 80 & $\mathrm{Bc}$ \\
& $21 \mathrm{DAI}$ & 78 & $\mathrm{C}$ \\
\hline
\end{tabular}

DAI, days after initial application. ${ }^{b}$ For a given main effect, means within a column followed by the same letter are not different according to Fisher's protected LSD $(\alpha=0.05)$. ' Glufosinate rates are in $\mathrm{g}$ ai ha ${ }^{-1}$.

block (site-year) were included in the model as random effects. Means were separated using Fisher's protected least significant difference (LSD) $(\alpha=0.05)$.

\section{Results and Discussion}

3.1. Palmer Amaranth. For Palmer amaranth control 3 weeks after the final application (WAF), the interaction between glufosinate rate and sequential application timing was not significant in the ANOVA $(p=0.08181)$ and was not interpreted. However, both the main effects of glufosinate rate $(p<0.0001)$ and sequential application timing $(p<0.0001)$ were significant for percent control 3 WAF and are presented in Table 3. As mentioned previously, all of the initial applications included $S$-metolachlor at $1390 \mathrm{~g} \mathrm{ha}^{-1}$; therefore, control ratings reflect emerged plants at the time of application. A glufosinate rate response was detected as the rate increased from 451 to $738 \mathrm{~g}$ ai ha ${ }^{-1}$ and control increased from $68 \%$ to $79 \%$, averaged across sequential application timing. No difference was observed between the 
TABLE 4: Effect of glufosinate rate and sequential application timing on Palmer amaranth control at harvest in Fayetteville, AR, in 2015, 2016, and 2017.

\begin{tabular}{|c|c|c|c|}
\hline \multirow[t]{2}{*}{$\begin{array}{l}\text { Glufosinate rate } \\
\left(\mathrm{g} \mathrm{ai} \mathrm{ha}^{-1}\right)\end{array}$} & \multirow{2}{*}{$\begin{array}{c}\text { Sequential application timing } \\
\text { None }\end{array}$} & \multicolumn{2}{|c|}{$\begin{array}{c}\text { Control }^{\mathrm{b}} \\
(\%)\end{array}$} \\
\hline & & 35 & 1 \\
\hline \multirow{4}{*}{451} & $7 \mathrm{DAI}$ & 80 & fgh \\
\hline & $10 \mathrm{DAI}$ & 81 & efg \\
\hline & 14 DAI & 76 & ghi \\
\hline & $21 \mathrm{DAI}$ & 73 & $\mathrm{i}$ \\
\hline \multirow{5}{*}{595} & None & 43 & $\mathrm{k}$ \\
\hline & $7 \mathrm{DAI}$ & 83 & def \\
\hline & 10 DAI & 83 & def \\
\hline & 14 DAI & 84 & cdef \\
\hline & $21 \mathrm{DAI}$ & 75 & hi \\
\hline \multirow{5}{*}{738} & None & 57 & $\mathrm{j}$ \\
\hline & 7 DAI & 86 & bcde \\
\hline & $10 \mathrm{DAI}$ & 89 & abcd \\
\hline & 14 DAI & 84 & cdef \\
\hline & $21 \mathrm{DAI}$ & 79 & fgh \\
\hline \multirow{5}{*}{882} & None & 57 & $\mathrm{j}$ \\
\hline & 7 DAI & 94 & a \\
\hline & $10 \mathrm{DAI}$ & 91 & $\mathrm{ab}$ \\
\hline & 14 DAI & 89 & $\mathrm{abc}$ \\
\hline & $21 \mathrm{DAI}$ & 87 & bcd \\
\hline
\end{tabular}

DAI, days after initial application. ${ }^{\mathrm{b}}$ Means within a column followed by the same letter are not different according to Fisher's protected LSD $(\alpha=0.05)$.

738 and $882 \mathrm{~g}$ ai ha ${ }^{-1}$ rates. The main effect of sequential application timing showed a clear benefit of applying a sequential application. Control was lowest (51\%) when no sequential application was applied, compared to $84 \%$ when a sequential application occurred $7 \mathrm{~d}$ after the initial application (DAI), averaged across glufosinate rates. As the length of time between sequential applications increases beyond $10 \mathrm{~d}$, control tended to decrease. For example, control with the sequential application occurring 10 DAI was $86 \%$, compared to $78 \%$ when the sequential application occurred 21 DAI.

At harvest, an interaction between glufosinate rate and sequential application timing was observed for percent control ( $p=0.00671$ ) (Table 4). However, most of the trends observed for control 3 WAF held true for the assessment at harvest. Considering the $451 \mathrm{~g}$ ai ha ${ }^{-1}$ rate of glufosinate at harvest, control when the sequential application occurred 10 DAI was $81 \%$, and control declined to $73 \%$ when time between applications increased to $21 \mathrm{~d}$. A single application was always inferior to treatments that contained a sequential, even when comparing different rates. For example, a single application of $882 \mathrm{~g}$ ai ha ${ }^{-1}$ provided only $57 \%$ control of Palmer amaranth at harvest, whereas two applications of $451 \mathrm{~g}$ ai ha ${ }^{-1} 21 \mathrm{~d}$ apart provided $73 \%$ control.

These data clearly demonstrate that if large Palmer amaranth is present at the time of a glufosinate application, two applications of $451 \mathrm{~g}$ ai ha $\mathrm{ha}^{-1} 7-14 \mathrm{~d}$ apart would be highly preferable to using a comparable amount of active ingredient in a single application (902 vs. $882 \mathrm{~g}$ ai ha $^{-1}$ total glufosinate for the sequential and single applications, respectively). It should be noted that 451 and $882 \mathrm{~g}^{\mathrm{ai}} \mathrm{ha}^{-1}$ are the lowest and highest labeled rates, respectively [19]. These data do not suggest that using partial rates in sequential applications would provide effective control compared to a labeled rate. Norsworthy et al. [4] recommended that using full labeled rates is an integral part of herbicide-resistance management. In fact, exposure to low doses is often used to rapidly generate herbicide resistance in greenhouse experiments. Busi and Powles [25] produced a rigid ryegrass (Lolium rigidum Gaud.) population with resistance to glyphosate in three rounds of low-dose recurrent selection, and similar experiments produced a Palmer amaranth population resistant to dicamba [26]. Thus, applications should be made at rates appropriate to achieve complete control and be only one component of a weed management plan.

3.2. Barnyardgrass and Broadleaf Signalgrass. For both barnyardgrass and broadleaf signalgrass, an interaction between glufosinate rate and sequential application timing was observed for percent control 3 WAF $(p=0.01401$, $p=0.01074$ for barnyardgrass and broadleaf signalgrass, respectively) (Table 5). Barnyardgrass control 3 WAF ranged from 55 to $92 \%$ and 55 to $91 \%$ for broadleaf signalgrass. A sharp rate response was observed for single applications (no sequential) as rates increased from 595 to $738 \mathrm{~g}$ ai ha ${ }^{-1}$, for both species. For barnyardgrass, control 3 WAF with $595 \mathrm{~g}$ ai $\mathrm{ha}^{-1}$ was $58 \%$ and increased to $71 \%$ when $738 \mathrm{~g}$ ai ha ${ }^{-1}$ was applied with no sequential application. However, few differences were observed between sequential application timings within a given rate, except at the $451 \mathrm{~g}$ ai ha $^{-1}$ rate. For example, broadleaf signalgrass control was greater when $451 \mathrm{~g}$ ai ha ${ }^{-1}$ was applied $14 \mathrm{~d}$ apart (86\%) compared to $21 \mathrm{~d}$ apart $(73 \%)$.

The analysis of percent control at harvest was similar for barnyardgrass and broadleaf signalgrass; the two-way interaction was not significant, and both the main effects (glufosinate rate and sequential application timing) were significant in the each of the models (refer to Table 6 for $p$ values). For both barnyardgrass and broadleaf signalgrass, control was not different among sequential application timings as long as a second application was made (Table 7). Making a sequential application 7 DAI improved barnyardgrass control by $21 \%$ and broadleaf signalgrass control by $19 \%$ compared to no sequential application, averaged across glufosinate rates. These results differ from Palmer amaranth control, for which control generally decreased as time between sequential applications increased. Thus, species may play a role in response to the length of time between two applications. The differences between species could also be due to morphological differences between monocots and dicots: the growing point on barnyardgrass and broadleaf signalgrass lies at the soil surface making it more difficult to intercept spray from a contact herbicide (i.e., glufosinate). Thus, grass species may be less responsive to time between sequential applications.

A gradual rate response was observed for both grass species for percent control assessed at harvest, averaged across sequential application timings. For both broadleaf 
TABLE 5: An interaction between glufosinate rate and sequential application timing observed on barnyardgrass and broadleaf signalgrass control 3 weeks after the final application in Fayetteville, AR, in 2015, 2016, and 2017.

\begin{tabular}{|c|c|c|c|c|c|}
\hline \multirow[b]{2}{*}{ Glufosinate rate $\left(\mathrm{g}\right.$ ai ha ${ }^{-1}$ ) } & \multirow[b]{2}{*}{ Sequential application timing } & \multicolumn{4}{|c|}{ Control $^{\mathrm{b}}(\%)$} \\
\hline & & \multicolumn{2}{|c|}{ Barnyardgrass } & \multicolumn{2}{|c|}{$\begin{array}{c}\text { Broadleaf } \\
\text { signalgrass }\end{array}$} \\
\hline \multirow{5}{*}{451} & None & 55 & $\mathrm{~g}$ & 55 & $\mathrm{e}$ \\
\hline & $7 \mathrm{DAI}$ & 82 & $c d$ & 73 & $\mathrm{~d}$ \\
\hline & $10 \mathrm{DAI}$ & 86 & $\mathrm{bc}$ & 78 & $c d$ \\
\hline & $14 \mathrm{DAI}$ & 76 & def & 86 & $\mathrm{ab}$ \\
\hline & $21 \mathrm{DAI}$ & 77 & def & 73 & $\mathrm{~d}$ \\
\hline \multirow{5}{*}{595} & None & 58 & g & 56 & $\mathrm{e}$ \\
\hline & $7 \mathrm{DAI}$ & 87 & $\mathrm{abc}$ & 79 & bcd \\
\hline & $10 \mathrm{DAI}$ & 87 & $a b c$ & 85 & $\mathrm{abc}$ \\
\hline & $14 \mathrm{DAI}$ & 87 & $\mathrm{bc}$ & 88 & $\mathrm{a}$ \\
\hline & $21 \mathrm{DAI}$ & 82 & cde & 87 & $\mathrm{a}$ \\
\hline \multirow{5}{*}{738} & None & 71 & $\mathrm{f}$ & 73 & $\mathrm{~d}$ \\
\hline & $7 \mathrm{DAI}$ & 90 & $\mathrm{ab}$ & 88 & $\mathrm{a}$ \\
\hline & $10 \mathrm{DAI}$ & 86 & $\mathrm{bc}$ & 88 & $\mathrm{a}$ \\
\hline & $14 \mathrm{DAI}$ & 89 & $\mathrm{ab}$ & 86 & $\mathrm{ab}$ \\
\hline & $21 \mathrm{DAI}$ & 86 & $\mathrm{bc}$ & 88 & $\mathrm{a}$ \\
\hline \multirow{5}{*}{882} & None & 75 & ef & 72 & $\mathrm{~d}$ \\
\hline & $7 \mathrm{DAI}$ & 94 & $\mathrm{a}$ & 91 & $\mathrm{a}$ \\
\hline & $10 \mathrm{DAI}$ & 92 & $\mathrm{ab}$ & 86 & $a b c$ \\
\hline & $14 \mathrm{DAI}$ & 91 & $a b$ & 90 & $\mathrm{a}$ \\
\hline & $21 \mathrm{DAI}$ & 88 & $\mathrm{abc}$ & 85 & $a b c$ \\
\hline
\end{tabular}

DAI, days after initial application. ${ }^{\mathrm{b}}$ Means within a column followed by the same letter are not different according to Fisher's protected LSD $(\alpha=0.05)$.

TABLE 6: Model effects and $p$ values obtained from the ANOVA for barnyardgrass control, broadleaf signalgrass control, and soybean yield collected at harvest.

\begin{tabular}{lccc}
\hline Model effect & & Control & \\
& Barnyardgrass & Broadleaf signalgrass & Soybean yield \\
\hline Glufosinate rate & & $p$ value & $<0.0001$ \\
Sequential application timing & $<0.0001$ & $<0.0001$ & $<0.0001$ \\
Glufosinate rate $*$ sequential application timing & $<0.0001$ & 0.2399 & 0.0726 \\
\hline
\end{tabular}

TABle 7: Percent control of barnyardgrass and broadleaf signalgrass at harvest for the main effects of glufosinate rate and sequential application timing, averaged over the other factors in Fayetteville, AR, in 2015, 2016, and 2017.

\begin{tabular}{|c|c|c|c|c|c|}
\hline \multirow{2}{*}{ Main effect } & \multirow{2}{*}{ Level } & \multicolumn{4}{|c|}{ Control $^{\mathrm{b}}(\%)$} \\
\hline & & \multicolumn{2}{|c|}{ Barnyardgrass } & \multicolumn{2}{|c|}{ Broadleaf signalgrass } \\
\hline \multirow{4}{*}{ Glufosinate rate ${ }^{c}$} & 451 & 69 & c & 68 & c \\
\hline & 595 & 75 & $\mathrm{~b}$ & 77 & $\mathrm{~b}$ \\
\hline & 738 & 79 & a & 79 & $a b$ \\
\hline & 882 & 80 & $\mathrm{a}$ & 81 & $\mathrm{a}$ \\
\hline \multirow{5}{*}{ Sequential application timing } & None & 59 & $\mathrm{~b}$ & 59 & $\mathrm{~b}$ \\
\hline & 7 DAI & 80 & $\mathrm{a}$ & 78 & $\mathrm{a}$ \\
\hline & $10 \mathrm{DAI}$ & 80 & $\mathrm{a}$ & 81 & $\mathrm{a}$ \\
\hline & $14 \mathrm{DAI}$ & 80 & $\mathrm{a}$ & 81 & $\mathrm{a}$ \\
\hline & $21 \mathrm{DAI}$ & 80 & $\mathrm{a}$ & 82 & $\mathrm{a}$ \\
\hline
\end{tabular}

DAI, days after initial application. ${ }^{\mathrm{b}}$ For a given main effect, means within a column followed by the same letter are not different according to Fisher's protected $\operatorname{LSD}(\alpha=0.05)$. ${ }^{\mathrm{c}} \mathrm{Glufosinate}$ rates are in $\mathrm{g}$ ai ha ${ }^{-1}$.

signalgrass and barnyardgrass, control was greatest when at least $738 \mathrm{~g}$ ai ha ${ }^{-1}$ was applied. Control of both species was $79 \%$ for the $738 \mathrm{~g}$ ai $\mathrm{ha}^{-1}$ rate, averaged across application timings.
3.3. Grain Yield. The response in grain yield to these various treatments generally followed the responses in weed control. The interaction between glufosinate rate and sequential application timings was not significant in the model 
TABLE 8: Soybean grain yield for the main effects of glufosinate rate and sequential application timing, averaged over the other factors in Fayetteville, AR, in 2015, 2016, and 2017.

\begin{tabular}{lccc}
\hline Main effect & Level & \multicolumn{2}{c}{ Yield $\left.^{\mathrm{b}} \mathrm{ha}^{-1}\right)$} \\
\hline \multirow{3}{*}{ Glufosinate rate } & & 2526 & $\mathrm{~b}$ \\
& 451 & 2620 & $\mathrm{~b}$ \\
& 595 & 2526 & $\mathrm{~b}$ \\
& 738 & 2762 & $\mathrm{a}$ \\
\hline \multirow{3}{*}{ Sequential application timing } & 882 & 2324 & $\mathrm{~d}$ \\
& None & 2701 & $\mathrm{ab}$ \\
& 7 DAI & 3949 & $\mathrm{a}$ \\
& 10 DAI & 2661 & $\mathrm{bc}$ \\
& 21 DAI & 2526 & $\mathrm{c}$ \\
\hline
\end{tabular}

DAI, days after initial application. ${ }^{\mathrm{b}}$ For a given main effect, means within a column followed by the same letter are not different according to Fisher's protected LSD $(\alpha=0.05)$. ${ }^{c}$ Glufosinate rates are in $\mathrm{g}$ ai ha ${ }^{-1}$.

(Table 6), but both main effects and data are presented in Table 8. Averaged across sequential application timings, soybean yield was greatest $\left(2,760 \mathrm{~kg} \mathrm{ha}^{-1}\right)$ when $882 \mathrm{~g}_{\text {ai ha }}{ }^{-1}$ was used. This result follows the weed control data, in which the control tended to be greatest when at least glufosinate at $738 \mathrm{~g} \mathrm{ha}^{-1}$ was applied, although control with $882 \mathrm{~g} \mathrm{ha}^{-1}$ tended to be numerically greater than $738 \mathrm{~g} \mathrm{ha}^{-1}$ (e.g., Tables 4 and 7 ).

For the main effect of sequential application timing, grain yield was lowest $\left(2,320 \mathrm{~kg} \mathrm{ha}^{-1}\right)$ when no sequential application was applied, averaged across glufosinate rates. For comparison, yield from the nontreated check was $1,150 \mathrm{~kg} \mathrm{ha}^{-1}\left(\mathrm{SE}=101 \mathrm{~kg} \mathrm{ha}^{-1}\right)$. The response in grain yield for the main effect of sequential application timing followed the response of Palmer amaranth control as opposed to the grass species; the yield tended to decline as time between sequential applications increased. For example, soybean yield was $2,700 \mathrm{~kg} \mathrm{ha}^{-1}$ when the sequential application occurred 7 DAI compared to $2,530 \mathrm{~kg} \mathrm{ha}^{-1}$ when the second application occurred 21 DAI.

\section{Conclusions}

Sequential applications of any rate provided superior weed control to a single application, implying the need to make two POST applications when large weeds are present at the time of the initial application. These results agree with Aulakh and Jhala [27] who determined that the applications of glufosinate 3-4 weeks apart generally had a greater control of a broad spectrum of weeds than single applications. Control of Palmer amaranth and grain yield declined as time between applications increased, suggesting that the follow-up application should occur 7-14 DAI. Furthermore, at least $738 \mathrm{~g} \mathrm{ha}^{-1}$ glufosinate should be used for both applications to maximize weed control. In the same study conducted by Aulakh and Jhala [27], control with herbicide programs that consisted of a PRE application followed by a POST application was usually superior to two applications of glufosinate POST. Therefore, the use of a PRE herbicide, use of full labeled rates, and avoiding applications to weeds beyond recommended sizes must be combined with other nonchemical and cultural tactics in an integrated weed management strategy focused on the soil seed bank to mitigate the risk of herbicide resistance [4].

These experiments were designed to evaluate a worstcase scenario where all weeds present are large and at high densities to provide recommendations when field situations are similar. As noted previously, both Palmer amaranth and barnyardgrass plants that emerge with the crop can cause severe yield losses [21]. Soybean plants that compete with weeds earlier in the season have phenological (e.g., earlyseason biomoass accumulation) and physiological changes that will not reverse, even if the weed competition is removed, that will ultimately reduce yield [23]. Therefore, minimizing the time weeds compete with the crop by utilizing PRE herbicides and timely POST applications, and effective sequential application timing of POST herbicides (when needed) is critical for preventing yield loss.

Other hard-to-control weed species may also present greater challenges than those evaluated in this experiment. Johnsongrass is a perennial species that has historically been a highly problematic weed in row-crop production $[28,29]$. In the absence of glyphosate, Johnson et al. [30] concluded that a single application of glufosinate alone is not sufficient to control Johnsongrass, and sequential applications of glufosinate plus clethodim were generally needed for acceptable control $[31,32]$. Weed spectrum and weather conditions may play a role in the recommendations of specific herbicide programs, and everything should be carried out to maximize the utility of the herbicides (i.e., glufosinate) utilized in those programs to achieve maximum weed control and mitigate the likelihood of resistance. For example, glufosinate is a contact herbicide, and the label recommends applications with medium to coarse droplet sizes and higher spray volumes $\left(\geq 141 \mathrm{~L} \mathrm{ha}^{-1}\right)$, both of which improve the performance of glufosinate [33-37].

\section{Data Availability}

The data used to support the findings of this study are available from the corresponding author upon request.

\section{Conflicts of Interest}

The authors declare that they have no conflicts of interest.

\section{Acknowledgments}

Funding for this research was provided by the Arkansas Soybean Promotion Board and Bayer CropScience.

\section{References}

[1] A. S. Culpepper, T. M. Webster, L. M. Sosnoskie, and A. C. York, "Glyphosate-resistant palmer amaranth in the United States," in Glyphosate Resistance in Crops and Weeds: History, Development, and Management, V. K. Nandula, Ed., John Wiley \& Sons, Singapore, pp. 195-212, 2010.

[2] I. Heap, "International survey of herbicide resistant weeds," February 2018, http://www.weedscience.com/summary/ home.aspx. 
[3] M. V. Bagavathiannan, J. K. Norsworthy, K. L. Smith, and P. Neve, "Modeling the simultaneous evolution of resistance to ALS- and ACCase-inhibiting herbicides in barnyardgrass (Echinochloa crus-galli) in Clearfield ${ }^{\circledR}$ rice," Weed Technology, vol. 28, no. 1, pp. 89-103, 2014.

[4] J. K. Norsworthy, S. M. Ward, D. R. Shaw et al., "Reducing the risks of herbicide resistance: best management practices and recommendations," Weed Science, vol. 60, no. 1, pp. 31-62, 2012.

[5] E. Coetzer, K. Al-Khatib, and D. E. Peterson, "Glufosinate efficacy on Amaranthus species in glufosinate-resistant soybean (Glycine max)," Weed Technology, vol. 16, no. 2, pp. 326-331, 2002.

[6] A. S. Culpepper, A. C. York, R. B. Batts, and K. M. Jennings, "Weed management in glufosinate- and glyphosate-resistant soybean (Glycine max)," Weed Technology, vol. 14, no. 1, pp. 77-88, 2000.

[7] M. L. Wiesbrook, W. G. Johnson, S. E. Hart, P. R. Bradley, and L. M. Wax, "Comparison of weed management systems in narrow-row, glyphosate-, and glufosinate-resistant soybean (Glycine max)," Weed Technology, vol. 15, no. 1, pp. 122-128, 2001.

[8] G. J. Steckel, L. M. Wax, F. W. Simmons, and W. H. Phillips II, "Glufosinate efficacy on annual weeds is influenced by rate and growth stage," Weed Technology, vol. 11, no. 3, pp. 484-488, 1997.

[9] A. H. Cobb and J. P. H. Reade, Herbicides and Plant Physiology, John Wiley \& Sons, West Sussex, UK, 2nd edition, 2010.

[10] W. E. Splittstoesser and L. A. Derscheid, "Effects of environment upon herbicides applied preemergence," Weeds, vol. 10, no. 4, pp. 304-307, 1962.

[11] M. Jursík, J. Soukup, J. Holec, J. Andr, and K. Hamouzová, "Efficacy and selectivity of pre-emergent sunflower herbicides under different soil moisture conditions," Plant Protection Science, vol. 51, no. 4, pp. 214-222, 2015.

[12] United States Department of Agriculture-National Agricultural Statistics Service (USDA-NASS), "Quick stats," February 2018, http://quickstats.nass.usda.gov/.

[13] R. E. DeLong, N. A. Slaton, C. G. Herron, and D. Lafex, "Soiltest and fertilizer sales data: summary for the 2016 growing season," in Wayne E Sabbe Arkansas Soil Fertility Studies 2016, N. A. Slaton, Ed., University of Arkansas Research Series 642, University of Arkansas University of Arkansas, Fayetteville, AR, USA, pp. 7-20, 2017.

[14] Natural Resources Conservation Service, "Web soil survey," 2018, https://websoilsurvey.sc.egov.usda.gov/.

[15] P. Jha and J. K. Norsworthy, "Soybean canopy and tillage effects on emergence of Palmer amaranth (Amaranthus palmeri) from a natural seed bank," Weed Science, vol. 57, no. 6, pp. 644-651, 2009.

[16] C. N. Bensch, M. J. Horak, and D. Peterson, "Interference of redroot pigweed (Amaranthus retroflexus), Palmer amaranth (A. palmeri), and common waterhemp (A. rudis) in soybean," Weed Science, vol. 51, no. 1, pp. 37-43, 2003.

[17] T. E. Klingaman and L. R. Oliver, "Palmer amaranth (Amaranthus palmeri) interference in soybeans (Glycine max)," Weed Science, vol. 42, no. 4, pp. 523-527, 1994.

[18] M. J. Horak and T. M. Loughin, "Growth analysis of four Amaranthus species," Weed Science, vol. 48, no. 3, pp. 347-355, 2000.

[19] Anonymous, Liberty Herbicide Product Label: Bayer Publication No. US84473405C, Bayer CropScience LP, Research Triangle Park, NC, USA, 2016.

[20] R. J. Zimdahl, Weed-Crop Competition-A Review, International Plant Protection Center, Oregon State University, Corvallis, OR, USA, 1980.
[21] P. Cowan, S. E. Weaver, and C. J. Swanton, "Interference between pigweed (Amaranthus spp.), barnyardgrass (Echinochloa crus-galli), and soybean (Glycine max)," Weed Science, vol. 46, no. 5, pp. 533-539, 1998.

[22] C. Halford, A. S. Hamill, J. Zhang, and C. Doucet, "Critical period of weed control in no-till soybean (Glycine max) and corn (Zea mays)," Weed Technology, vol. 15, no. 4, pp. 737-744, 2001.

[23] E. Green-Tracewicz, E. R. Page, and C. J. Swanton, "Light quality and the critical period for weed control in soybean," Weed Science, vol. 60, no. 1, pp. 86-91, 2012.

[24] D. C. Blouin, E. P. Webster, and J. A. Bond, "On the analysis of combined experiments," Weed Technology, vol. 25, no. 1, pp. 165-169, 2011.

[25] R. Busi and S. B. Powles, "Evolution of glyphosate resistance in a Lolium rigidum population by glyphosate selection at sublethal doses," Heredity, vol. 103, no. 4, pp. 318-325, 2009.

[26] P. Tehranchian, J. K. Norsworthy, S. Powles et al., "Recurrent sublethal-dose selection for reduced susceptibility of Palmer amaranth (Amaranthus palmeri) to dicamba," Weed Science, vol. 65, no. 2, pp. 206-212, 2017.

[27] J. S. Aulakh and A. J. Jhala, "Comparison of glufosinate-based herbicide programs for broad-spectrum weed control in glufosinate-resistant soybean," Weed Technology, vol. 29, no. 3, pp. 419-430, 2015.

[28] C. G. McWhorter and E. E. Hartwig, "Effectiveness of preplanting tillage in relation to herbicides in controlling Johnsongrass for soybean production," Agronomy Journal, vol. 57, no. 4, pp. 385-389, 1965.

[29] C. G. McWhorter, "Introduction and spread of johnsongrass in the United States," Weed Science, vol. 19, no. 5, pp. 496-500, 1971.

[30] W. G. Johnson, J. Li, and J. D. Wait, "Johnsongrass control, total nonstructural carbohydrates in rhizomes, and regrowth after application of herbicides used in herbicide-resistant corn (Zea mays)," Weed Technology, vol. 17, no. 1, pp. 36-41, 2003.

[31] D. B. Johnson, J. K. Norsworthy, and R. C. Scott, "Herbicide programs for controlling glyphosate-resistant johnsongrass (Sorghum halepense) in glufosinate-resistant soybean," Weed Technology, vol. 28, no. 1, pp. 10-18, 2014.

[32] C. J. Meyer, J. K. Norsworthy, D. O. Stephenson, M. T. Bararpour, R. L. Landry, and B. C. Woolam, "Control of johnsongrass in the absence of glyphosate in midsouth cotton production systems," Weed Technology, vol. 29, no. 4, pp. 730-739, 2015.

[33] C. F. Creech, J. G. Moraes, R. S. Henry, J. D. Luck, and G. R. Kruger, "The impact of spray droplet size on the efficacy of 2,4-D, atrazine, chlorimuron-methyl, dicamba, glufosinate, and saflufenacil," Weed Technology, vol. 30, no. 2, pp. 573-586, 2016.

[34] C. F. Creech, R. S. Henry, R. Werle, L. D. Sandell, A. J. Hewitt, and G. R. Kruger, "Performance of postemergence herbicides applied at different carrier volume rates," Weed Technology, vol. 29, no. 3, pp. 611-624, 2015.

[35] R. E. Etheridge, W. E. Hart, R. M. Hayes, and T. C. Mueller, "Effect of venturi-type nozzles and application volume on postemergence herbicide efficacy," Weed Technology, vol. 15, no. 1, pp. 75-80, 2001.

[36] M. Knoche, "Effect of droplet size and carrier volume on performance of foliage-applied herbicides," Crop Protection, vol. 13, no. 3, pp. 163-178, 1994.

[37] C. J. Meyer, J. K. Norsworthy, G. R. Kruger, and T. Barber, "Influence of droplet size on efficacy of the formulated products Engenia ${ }^{\mathrm{TM}}$, Roundup Powermax ${ }^{\circledR}$, and Liberty ${ }^{\circledR}, "$ Weed Technology, vol. 29, no. 4, pp. 641-652, 2015. 